\title{
Composition and Diversity of Aquatic Insects at Hutan Lipur Bukit Soga Perdana, Batu Pahat, Johor
}

\author{
Mohammad-Zulhusni Zakaria and Maryati Mohamed* \\ Center of Research for Sustainable Uses of Natural Resources, \\ Faculty of Applied Science and Technology, Universiti Tun Hussein Onn Malaysia, \\ 86400 Parit Raja, Batu Pahat, Johor, Malaysia.
}

Received 30 September 2017; accepted 7 February 2018; available online 1 August 2018

DOI: https://10.30880/jst.2018.10.02.002

\begin{abstract}
Human activities such as agriculture would negatively affect the quality of water sources and becomes a factor to the reduction of the composition of aquatic insects. A study was conducted to determine the composition of aquatic insects and correlation made between its composition and habitat in Soga Perdana Amenity Forest or locally known as Hutan Lipur Soga Perdana (HLSP), Batu Pahat, Johor. Samples were collected by using Kicking net for three days. A total of 794 individuals of aquatic insects representing 31 families from seven orders were collected. The orders ranked from the most family rich to the least showed that Diptera has seven families (22.6\%); Trichoptera six families (19.4\%); Ephemeroptera with five families (16.1\%); Odonata, four families $(12.9 \%)$; Coleoptera, four families (12.9\%), Hemiptera, three families $(9.7 \%)$ and Plecoptera, two (6.5\%). Most abundant were from families Leptophelibidae (Ephemeroptera with 131 individuals), Simuliidae (Diptera with 95 individuals) and Heptageniidae (Ephemeroptera with 92 individuals). Further analysis were carried out using several assessment index which were normally used. In this study Hilsenhoff Biotic Index (HBI), Biological Monitoring Working Party (BWMP) and EPT index were calculated. Results showed that HLBSP water body is of good quality and observed to be free from any anthropogenic activities. Eventhough with quantitatively limited supply, the available water bodies in this area supported high taxa richness with 31 families. For future conservation, works to preserve water bodies at HLBSP have to be done, since it is a water supply to maintain the forest regeneration in the reserve. Maintaining HLBSP is critical, because it plays an important ecological role as the green lung for the highly industrial district of Batu Pahat.
\end{abstract}

Keywords: Aquatic insects; green lung; species diversity; species richness.

\section{Introduction}

Water bodies are sensitive toward changes of environment. Water quality could change if there are any human activities such as industrial, agricultural and human settlement activities nearby. In fact, 6-10\% of all species all over the world are inhibit the freshwater ecosystem and from 126,000 freshwater animal about $60.4 \%$ of them are insects [1,2]. Because of that, freshwater ecosystems were considered as biodiversity hotspot which are very fragile ecosystems due to habitat losses and other anthropogenic activities [3]. Truthfully, freshwater ecosystems were considered as harsh habitats for small bodies animals despite that aquatic insects still manage to survive successfully because of wide range of adaptations [4]. Besides, aquatic insects play an important roles in water quality monitoring since they were very sensitive to the environmental changes such as physical, chemical and biological conditions and also inhibit in various type of water bodies and they have both of group that can only found in good water quality and also can be tolerate with poor water quality [5]. Human activities such as agricultural that cause fertilization run off to the water bodies could led to deterioration of the environment. In Peninsular Malaysia, water used are mostly from the network of rivers and streams. There are about 150 major river basins that form water bodies in Peninsular Malaysia. The main water source in Johor comes from Sungai Johor. At $122.7 \mathrm{~km}$ long, it supplies an area of 2,636 km ${ }^{2}$ and originates from Gunung Gemuruh that flows through southeastern part of Johor. There are four main tributaries that flow in Sungai Johor: Sayong, Linggiu, Tiram and Lebam Rivers. Sungai Johor and its tributaries are important water sources not only in Johor state but also for Singapore. $0.25 \times 10^{6}$ $\mathrm{m}^{3} /$ day of water is drawn from Sungai Johor near Kota Tinggi by Syarikat Air Johor (SAJ) and Public Utility Board of Singapore, and this has been occurring since the mid-1960's. In addition, under 1962 agreement with Malaysia that expired in 2061, national water agency 
PUB were to receive about 1.1 billion litres raw water daily from Sungai Johor River and in return, Singapore would sell about 22.7 million litres of treated water to Johor each day [6].

Johor is a fast developing state with manufacturing and agricultural being the major industries. As stated by World Library Foundation [26], Batu Pahat is ranked second largest manufacturing industrial town in Johor; mainly in textiles, electronics, food-processing, timber, porcelain and plastic industries. In Malaysia, 50\% of textiles exported comes from Batu Pahat and about 300 garment and textile factories are operating in Batu Pahat [7]. In agricultural industry, Batu Pahat have the largest rubber, palm oil, coconut, and cocoa plantations in Johor.

There are indications that industrial activities may cause environmental degradations and lead to many problems such as loss of biodiversity, impact on human health, ozone layer depletion, negative tourism industry and economic impact. The loss of clean water sources may affects many organisms such as wildlife and aquatic organisms that relies on that source. In this article, the composition of aquatic insects and correlation between its composition and habitat in Soga Perdana Amenity Forest or locally known as Hutan Lipur Soga Perdana (HLSP), Batu Pahat, Johor is highlighted.

HLSP is a highland dipterocarp forest with rich diversity in flora and fauna [8] and comprises of several type of water bodies which are small stream, temporary ponds, and lakes. These water bodies provides habitat for aquatic insects. Furthermore, HLSP is also the green lung for Batu Pahat district, because it is the only green space that could provide a healthier environment than other surrounding areas that are busy with industrial activities. However, water bodies here becomes more shallow toward the dry season that leads to the decreasing of diversity in aquatic insects. Some aquatic insects need a good water condition to live. HLSP has been a recreation parks for many years for people living in Batu Pahat and some form of monitoring ought to be carried out to ensure maintenance of clean environment.

Since a long time ago, aquatic insects were widely known as viable bioindicators for good or poor water qualities based on their sensitivity toward environmental change [9]. There was a study conducted by Iliopoulou-Georgudaki et al. [10] that mentions the advantages of monitoring by using bioindicator instead of assessing toxicant pollutants because its more reliable and inexpensive and also they reflect overall ecological quality and integrate the effects of different stressors providing a broad measure of their impact and an ecological measurement of fluctuating environmental conditions. Thus as an alternative, insects could be used as bioindicator because it is faster and more economical. Drastic and rapid changes of environment due to socio-economic development in Malaysia requires continuous regular and frequent water quality assessments and this would need the authorities to use practical instruments such as aquatic insects as bioindicator because of their advantages.

\section{Methodology}

Hutan Lipur Soga Perdana (HLSP) is located $5 \mathrm{~km}$ from Batu Pahat through Jalan Kluang-Batu Pahat and $130 \mathrm{~km}$ from Johor Bharu. Samplings were conducted in a small stream at HLSP. Three sampling stations were set up which was at the lower, middle and upper part of the stream. Distance between the three stations was about $100 \mathrm{~m}$. Elevation varied from 45 to $134 \mathrm{~m}$ ASL. There are three sub-stations in each station. Basically, site A (station at the upper part) represents less disturbed area, whereas site B (station at the middle part of the stream) and site $C$ (station in the lower part of the stream) represent the disturbed areas. There were some pools with stagnant water bodies, alongside the slow flowing stream, in site $\mathrm{C}$ (Table 1)

Table 1 Sampling information with description of sampling sites.

\begin{tabular}{lll}
\hline Site & Location & $\begin{array}{l}\text { Site } \\
\text { description }\end{array}$
\end{tabular}

\begin{tabular}{|c|c|c|}
\hline $\begin{array}{l}\text { (A) Higher } \\
\text { elevation } \\
(134 \mathrm{~m})\end{array}$ & $\begin{array}{l}\mathrm{N} 01^{\mathrm{O}} 51.067^{\prime}, \\
\text { E } 102^{\mathrm{O}} 57.618^{\prime}\end{array}$ & $\begin{array}{l}\text { Small, slow } \\
\text { flowing } \\
\text { water, with } \\
\text { mixed } \\
\text { bottom } \\
\text { substrate. }\end{array}$ \\
\hline $\begin{array}{l}\text { (B) Middle } \\
\text { elevation } \\
(57 \mathrm{~m})\end{array}$ & $\begin{array}{l}\text { N } 01^{\circ} 50.978 \\
\text { E } 102^{\circ} 57.585\end{array}$ & $\begin{array}{l}\text { Small, slow } \\
\text { flowing } \\
\text { water with } \\
\text { rocky } \\
\text { bottom. }\end{array}$ \\
\hline
\end{tabular}




\begin{tabular}{lll} 
(C) Lower & N 01050.938', & Small, slow \\
elevation & E 102 57.600 & flowing \\
$(45 \mathrm{~m})$ & & water with \\
& & sandy bottom \\
& and grasses \\
& at both \\
& banks, with \\
& few stagnant \\
& water pools \\
& alongside \\
\hline
\end{tabular}

Specimens were collected using Kicking net (size 18 inch $\times 9$ inch with mesh size $900 \mu \mathrm{m}$ ). Specimens were sorted alive in the field and preserved in $70 \%$ ethanol. In the laboratory specimens were identified, until the family level. 'Freshwater Invertebrates of the Malaysia Region' by [7] was used as the main reference for the identification process. Three biological indexes were used (1) EPT taxa richness, refer to the total number of Ephemeroptera, Plecoptera, and Trichoptera group per total number of taxa X 100\%, (2) Hilsenhoff Biotic Index followed by formula $H B I=\Sigma n i \times$ $a i / N$ and (3) Biological Monitoring Work Party (BMWP) to classify water from excellent water quality to poor water quality. In order, to determine the diversity of aquatic insects at sampling areas Shannon diversity index were used.

\section{Result}

A total of 794 individual aquatic insects from seven orders belonging to 31 families were collected and preserved (Table 2). Seven orders which were ranked from the most abundant to the least were as follow: Ephemeroptera, Plecoptera, Trichoptera, Odonata, Hemiptera, Coleoptera, and Diptera. The highest number of individuals collected were from site A (Station 1) with 292 individuals followed by site $C$ (Station 3) with 263 individuals and site B (Station 2) with 239 individuals. Family Leptophlebiidae from Order Ephemeroptera was the most dominant with 131 individuals collected followed by Simuliidae from Order Diptera with 95 individuals and Heptageniidae from Order Ephemeroptera with 92 individuals. In terms of family richness, Diptera was ranked as the richest order with seven families followed by Trichoptera (six), Ephemeroptera (five), Odonata (four), Coleoptera (four), Hemiptera (three) and Plecoptera (two).
Table 2 Abundance of aquatic insects from various families sampled from three sites in Hutan Lipur Soga Perdana

\begin{tabular}{|c|c|c|c|c|}
\hline Order & Family & $\begin{array}{c}\text { Site } \\
\text { A }\end{array}$ & $\begin{array}{c}\text { Site } \\
\text { B }\end{array}$ & $\begin{array}{c}\text { Site } \\
\text { C }\end{array}$ \\
\hline \multirow[t]{5}{*}{$\begin{array}{l}\text { Epheme } \\
\text { roptera }\end{array}$} & $\begin{array}{l}\text { Siphlonu } \\
\text { ridae }\end{array}$ & 21 & 2 & 3 \\
\hline & $\begin{array}{l}\text { Heptage } \\
\text { niidae }\end{array}$ & 25 & 44 & 23 \\
\hline & $\begin{array}{l}\text { Leptophle } \\
\text { biidae }\end{array}$ & 65 & 33 & 33 \\
\hline & Tricorytidae & 7 & 12 & 9 \\
\hline & Baetidae & 21 & 16 & 7 \\
\hline \multirow[t]{2}{*}{$\begin{array}{l}\text { Plecop } \\
\text { tera }\end{array}$} & Nemouridae & 5 & 0 & 0 \\
\hline & Perlidae & 8 & 2 & 17 \\
\hline \multirow[t]{6}{*}{$\begin{array}{l}\text { Trichop } \\
\text { tera }\end{array}$} & $\begin{array}{l}\text { Hydrop } \\
\text { tilidae }\end{array}$ & 0 & 0 & 1 \\
\hline & $\begin{array}{l}\text { Hydro } \\
\text { pscyhidae }\end{array}$ & 6 & 0 & 2 \\
\hline & $\begin{array}{l}\text { Helioco } \\
\text { psychidae }\end{array}$ & 1 & 0 & 7 \\
\hline & $\begin{array}{l}\text { Philopota } \\
\text { Midae }\end{array}$ & 15 & 37 & 8 \\
\hline & $\begin{array}{l}\text { Phryga } \\
\text { neidae }\end{array}$ & 0 & 0 & 1 \\
\hline & $\begin{array}{l}\text { Rhyaco } \\
\text { philidae }\end{array}$ & 1 & 1 & 0 \\
\hline \multirow[t]{4}{*}{ Odonata } & $\begin{array}{l}\text { Amphip } \\
\text { terygidae }\end{array}$ & 2 & 0 & 7 \\
\hline & Euphaeidae & 0 & 0 & 6 \\
\hline & Gomphidae & 1 & 4 & 3 \\
\hline & $\begin{array}{l}\text { Platystic } \\
\text { tidae }\end{array}$ & 5 & 4 & 1 \\
\hline \multirow[t]{3}{*}{$\begin{array}{l}\text { Hemip } \\
\text { tera }\end{array}$} & Veliidae & 9 & 4 & 7 \\
\hline & Gerridae & 9 & 13 & 6 \\
\hline & $\begin{array}{l}\text { Mesove } \\
\text { liidae }\end{array}$ & 2 & 0 & 1 \\
\hline \multirow[t]{4}{*}{$\begin{array}{l}\text { Coleop } \\
\text { tera }\end{array}$} & Psephenidae & 3 & 0 & 2 \\
\hline & Elmidae & 2 & 2 & 2 \\
\hline & $\begin{array}{l}\text { Chrysome } \\
\text { lidae }\end{array}$ & 1 & 0 & 0 \\
\hline & Scirtidae & 19 & 6 & 1 \\
\hline \multirow[t]{6}{*}{ Diptera } & $\begin{array}{l}\text { Ceratopogon } \\
\text { idae }\end{array}$ & 5 & 1 & 0 \\
\hline & Simuliidae & 10 & 23 & 62 \\
\hline & Tipuliidae & 18 & 10 & 27 \\
\hline & Athericidae & 28 & 23 & 26 \\
\hline & Limoniidae & 3 & 0 & 0 \\
\hline & Tabanidae & 0 & 1 & 1 \\
\hline
\end{tabular}




\begin{tabular}{|r|l|c|c|c|}
\hline & Dixidae & 0 & 1 & 0 \\
\hline Total & & 292 & 239 & 263 \\
\hline
\end{tabular}

Comparing sites to a number of families represented (Table 3), site $\mathrm{A}$ in the forested area had the highest with 27 families. However site $\mathrm{B}$ also in the forested area had a slightly lower family number (20 families) than A and C. C had 25 families. Perhaps the presence of stagnant water pools and grassy banks provided resources (food and habitat) for more families of aquatic to live in. Based on Shannon diversity index value (Table 4), there are no significant difference between site A, B and C.

Table 3 Number of families in site A, B and C of Hutan Lipur Soga Perdana, Batu pahat Johor

\begin{tabular}{|c|c|}
\hline Site & Number of families sampled \\
\hline A & 26 \\
\hline B & 20 \\
\hline C & 25 \\
\hline
\end{tabular}

Table 4 Shannon diversity index value for each sampling station.

\begin{tabular}{|l|l|l|l|l|}
\hline $\begin{array}{l}\text { Sampling } \\
\text { station }\end{array}$ & $\begin{array}{l}\text { Site } \\
\text { A }\end{array}$ & $\begin{array}{l}\text { Site } \\
\text { B }\end{array}$ & $\begin{array}{l}\text { Site } \\
\text { C }\end{array}$ & Overall \\
\hline $\begin{array}{l}\text { Shannon } \\
\text { diversity } \\
\text { index }\end{array}$ & 2.731 & 2.456 & 2.574 & 2.761 \\
\hline
\end{tabular}

Table 5 summarizes results of analyses based on composition of families and abundant of aquatic insects at HLSP. For HBI values there were no significant differences between each site; all sites showed water with excellent to very good quality. Sites A and B being in the forested area tend to have slightly better water quality. Generally, scores from BMWP also showed water quality of good to moderately good. Influenced by the slightly lower family representation and abundance (Tables 5 and 6). Site B tend to have water with moderately good quality. The BMWP score for site $\mathrm{A}$ and $\mathrm{C}$ were also slightly higher than site B (Tables 5 and 6); perhaps for the same reason stated above. For EPT taxa richness, the total families collected was 11 for site A, eight for site B and 11 for site $\mathrm{C}$ and 13 families for combining all three sites. The relative high number of EPT indicated a good water quality (Table 7).
Table 5 Classifications of water quality in Hutan Lipur Soga Perdana based on biological indices.

\begin{tabular}{|l|l|l|l|l|l|}
\hline $\begin{array}{l}\text { H } \\
\text { BI }\end{array}$ & Class & $\begin{array}{l}\text { B } \\
\text { W } \\
\text { MP }\end{array}$ & Class & $\begin{array}{l}\text { EPT } \\
\text { Val. }\end{array}$ & Class \\
\hline $\begin{array}{l}3.4 \\
7\end{array}$ & $\begin{array}{l}\text { Excel } \\
\text { lent }\end{array}$ & $\begin{array}{l}11 \\
9\end{array}$ & Good & 11 & $\begin{array}{l}\text { Very } \\
\text { good }\end{array}$ \\
\hline $\begin{array}{l}3.4 \\
8\end{array}$ & $\begin{array}{l}\text { Excel } \\
\text { lent }\end{array}$ & 92 & $\begin{array}{l}\text { Modera } \\
\text { tely- } \\
\text { good }\end{array}$ & 8 & good \\
\hline $\begin{array}{l}3.7 \\
4\end{array}$ & $\begin{array}{l}\text { Very } \\
\text { good }\end{array}$ & $\begin{array}{l}11 \\
1\end{array}$ & Good & 11 & $\begin{array}{l}\text { Very } \\
\text { good }\end{array}$ \\
\hline $\begin{array}{l}3.4 \\
2\end{array}$ & $\begin{array}{l}\text { Excel } \\
\text { lent }\end{array}$ & $\begin{array}{l}13 \\
5\end{array}$ & Good & 13 & $\begin{array}{l}\text { Very } \\
\text { good }\end{array}$ \\
\hline
\end{tabular}

Table 6 Biotic index criteria for water quality ratings. Water quality based on Family Biotic Index [11].

\begin{tabular}{|l|l|}
\hline $\begin{array}{c}\text { Biotic index criteria } \\
\text { (BMWP) }\end{array}$ & $\begin{array}{l}\text { Water quality } \\
\text { rating }\end{array}$ \\
\hline$>150$ & I Excellent \\
\hline $101-150$ & II Good \\
\hline $51-100$ & $\begin{array}{l}\text { III Moderately- } \\
\text { good }\end{array}$ \\
\hline $17-50$ & IV Fair \\
\hline $0-16$ & V Poor \\
\hline
\end{tabular}

\begin{tabular}{|c|c|c|}
\hline $\begin{array}{l}\text { Biotic } \\
\text { Index }\end{array}$ & $\begin{array}{l}\text { Water } \\
\text { quality }\end{array}$ & $\begin{array}{l}\text { Degree of organic } \\
\text { pollution }\end{array}$ \\
\hline $\begin{array}{c}0.00- \\
3.50\end{array}$ & Excellent & $\begin{array}{l}\text { No apparent } \\
\text { organic pollution }\end{array}$ \\
\hline $\begin{array}{c}3.51- \\
4.50\end{array}$ & $\begin{array}{l}\text { Very } \\
\text { good }\end{array}$ & $\begin{array}{l}\text { Possible slight } \\
\text { organic pollution }\end{array}$ \\
\hline $\begin{array}{c}4.51- \\
5.50 \\
\end{array}$ & Good & $\begin{array}{l}\text { Some organic } \\
\text { pollution }\end{array}$ \\
\hline $\begin{array}{c}5.51- \\
6.50 \\
\end{array}$ & Fair & $\begin{array}{l}\text { Fairly significant } \\
\text { organic pollution }\end{array}$ \\
\hline $\begin{array}{c}6.51- \\
7.50 \\
\end{array}$ & $\begin{array}{l}\text { Fairly } \\
\text { poor }\end{array}$ & $\begin{array}{l}\text { Significant } \\
\text { organic pollution }\end{array}$ \\
\hline $\begin{array}{c}7.51- \\
8.50\end{array}$ & Poor & $\begin{array}{l}\text { Very significant } \\
\text { organic pollution }\end{array}$ \\
\hline $\begin{array}{c}8.51- \\
10.0\end{array}$ & Very poor & $\begin{array}{l}\text { Severe organic } \\
\text { pollution }\end{array}$ \\
\hline
\end{tabular}

Table 7 Water Quality Classification Based on EPT Value [12,13,14].

\begin{tabular}{|l|l|}
\hline EPT Value & Water Quality \\
\hline$<2$ & Polluted \\
\hline $2-5$ & Clean \\
\hline $6-10$ & Good \\
\hline$>10$ & Very Good \\
\hline
\end{tabular}




\section{Discussion}

With regard to presence of specific families, Leptophlebiidae is the most abundant especially in site A because species in this family could adapt very well in stream with sedimented bottom. It is commonly found among roots at bank of the stream [7]. Leptophlebiidae also are included in xylophilous fauna which typically occur on or within submerged wood [15]. Wood has many benefits to aquatic insects, such as food source, living space, concealment, oviposition and attachment substrate, refuge from predators, protection from adverse abiotic conditions and emergence sites for aquatic insects [16]. Moreover, it is well suited condition in site A.

Habitat preference is the primary factor for simuliid to be found in abundance especially in site C. Characteristic of site $\mathrm{C}$ is of mainly muddy substrates at bottom of riverbed, and slow flowing water. Since simuliid is a filterfeeding organism which allows simuliid to attach to substrates and get their food by filtering the water through its labral fans at the mouthpart and no need much energy to obtain their food because water current were helping them [17,18]. In addition, the presence of simuliid could give a good sign because simuliid could not tolerate pollution [19].

Family Athericidae was numerously found in every sites at HLSP to show the stream is the water body that have a stable substrate and low in $\mathrm{pH}$ value were expected. As stated in Yule and Yong [7], family Athericidae is good indicator of substrate stability and that $\mathrm{pH}$ can be limiting because it could not stand high acidic water. Their habitat preference also matched very well with study sites since it was mostly found in moist microhabitat on the banks, in sand, gravel or soft soils and sometimes found sheltering in hygrophilous plants.

Based on biotic indices values, it shows ranging from good to excellent in water quality from biological perspective and since, no sign of anthropogenic activities occured at HLSP and as we know, anthropogenic activies such as sedimentation, sewage/ nutrient runoff and agricultural pesticides would give major impact on water qualities [20]. Among the EPT group, Plecoptera were found with least abundance as they are insects that very sensitive and intolerance to pollution [21].
Even though, the abundance of aquatic insects at site B was lower, it still had a good water quality. Reasons why the abundance of aquatic insects at site $\mathrm{B}$ was slightly lower than $\mathrm{A}$ and $\mathrm{C}$ are the presence of very limited water body. Because a good habitat supposely heterogenious habitat, which including all elements needed such as both slow and fast moving water, wood debris, substrate variety, well-vegetated and stable banks [19]. Lacking of these good habitat elements and water chemistry would reduce the diversity of aquatic macroinvertebrates [22].

Last but not least, the main threat at HLSP is human alteration to the water bodies which directly disturb the home of aquatic insects and also the presence of invasive species of fishes that were released by local visitors.

\section{Conclusion}

For future conservation, efforts should be done to preserve water bodies at HLSP since good water is needed to maintain the forest reserve regeneration. Maintaining HLSP is critical since it plays an important ecological role as the green lung for the highly industrial district of Batu Pahat. Sustainable development for Malaysia, especially in urban areas, should also consider the presence of green lung as has been implemented worldwide. Systematic management plan could give a huge advantage such as financial expenditure, time and the most important thing is environment itself.

\section{Acknowledgment}

We were grateful to the Universiti Tun Hussein Onn Malaysia (UTHM) for providing funding for running this project. This project was fully supported by the contract grant (Vot no. U393) under UTHM allocated to The second author. Gratitude is also for Forest Officer at Johor State Forestry Department for permitting us permission and assist us to run this project at HLSP.

\section{References}

[1] Dudgeon, D., Arthington, A. H., Gessner, M. O., Kawabata, Z. I., Knowler, D. J., Lévêque, C., Sullivan, C. A. 2006. "Freshwater Biodiversity: Importance, Threats, Status and Conservation Challenges". Biological Reviews of the 
Cambridge Philosophical Society, Vol. 81. No. 2 pp. $163-182$.

[2] Balian, E. V., Lévêque, C., Segers, H., \& Martens, K. 2008. "The Freshwater Animal Diversity Assessment: An Overview of the Results" in Hydrobiologia Vol. 595. pp. 627-637.

[3] Conservation International (2014). https://www.conservation.org/

How/Pages/Hotspots.aspx

[4] The Straits Times (2017). 'Enough Water in Linggiu Dam to Supply to S'pore: Johor official'.

http://www.straitstimes.com/asia/seasia/enough-water-in-linggiu-dam-tosupply-to-spore-johor-official

[5] Budin, K., Ahmed, A., Abdullah, N., and Dawalih, M (2007). "Correlation Analysis on Water Quality Parameter with Aquatic Insects Abundance in Telipok River, Sabah, Malaysia". 12th WSEAS International Conference on Applied Mathematics, Sabah, Malaysia.

[6] Wahizatul, A.A., Long, S.H., and Ahmad, A (2011). "Composition and Distribution of Aquatic Insect Communities in Relation to Water Quality in Two Freshwater Streams of Hulu Terengganu, Terengganu.” Journal of Sustainability Science and Management, Vol 6. No. 1 pp.148-155

[7] Yule, C.M. and Yong, H.S (2004). Freshwater Invertebrates of the Malaysian Region. Malaysia: Academy of Sciences Malaysia.

[8] Johor State Forestry Department. (2016). "Soga Perdana Amenity Forest." Retrieved from http://johor.forestry.gov.my/index.php/ maklumatperhutanan/pembangunan/201 5-12 15-03-32-07/hutan-lipur/hutanlipur-soga-perdana

[9] Resh, V., \& Betts, E. (2007). Bioindicators of Strawberry Creek. Department of Integrative Biology, University of California.

[10] Iliopoulou-Georgudaki, J., Kantzaris, V., Katharios, P., Kaspiris, P., Georgiadis, T., and Montesantou, B (2003). "An Application of Different Bioindicators for Assessing Water Quality: A Case Study in the Rivers Alfeios and Pineios
(Peloponnisos, Greece)." in Ecological Indicators, Vol. 2. No. 4 pp. 345-360.

[11] Hilsenhoff, W. L. (1977). Use of Arthropods to Evaluate Water Quality of Streams. Technical Bulletin.

[12] Bode, R.W (1988). Quality Assurance Work Plan for Biological Stream Monitoring in New York State. New York State Department of Environmental Conservation, Albany, New York.

[13] Bode, R.W., Novak, M.A., and Abele, L.A (1997). Biological Stream Testing. NYS Department of Environmental Protection, Division of Water, Bureau of Monitoring and Assessment, Stream Monitoring Unit, USA.

[14] Keçi, E., Paparisto, A., Pepa, B. and Xhaxhiu, K (2012). "Use of Benthic Macro-Invertebrate Taxones as Biological Indicators in Assessing Water Quality of Erzeni River, Albania, During 2011-2012." International Journal of Basic \& Applied Sciences. Vol. 12. No. 6 pp. $165-169$

[15] World Library Foundation (2017). Batu Pahat (Town). World Heritage Encyclopedia.

http://www.worldebooklibrary.org/articl es/eng/Batu_Pahat_(town)

[16] Anderson, N.H., Steedman, R.J., and Dudley, T (1984). "Patterns of Exploitation by Stream Invertebrates of Wood Debris (Xylophagy)." Vern. Internat. Verein. Limnol. Vol. 22. pp. 1847-1852.

[17] Chance, M.M., and Craig, D.A (1986). "Hydrodynamics and Behaviour of Simuliidae Larvae (Diptera)." Can. .I. Zool. Vol. 64. pp. 1295- 1309.

[18] Cummins, K. W., and Meritt, R. W (2008). Ecology and Distribution of Aquatic Insects. An Introduction to the Aquatic Insects of North America. Dubuque, Iowa: Kendall/Hunt Publishing Company.

[19] New, T.R (1984). Insect Conservation. an Australian Perspective. Dordrecht, Netherlands.

[20] Ward, J.V (1992). Aquatic Insect Ecology. 1. Ecology and Habitat. John Wiley \& Sons, Inc.

[21] Galdean, N., Callisto, M., and Barbosa, F.A.R (2000). "Lotic Ecosystems of Serra do Cipo, Southeast Brazil: Water Quality and A Tentative Classification 
Journal of Science and Technology, Vol. 10 No. 2 (2018) p. 10-16

Based on The Benthic Macroinvertebrate Community". Aquatic Ecosystem Health and Management Society, Vol. 3. pp. 545-552.

[22] Susheela, P., Radha, R., and Ezhili, N (2014). Diversity and Distribution of Aquatic Insect Population in Singanallur Lake, Coimbatore, Tamil Nadu, India. in Journal of International Academic Research for Multidisciplinary, Vol. 2. No. 5 pp. 141147 